\title{
Constitutional Review di Indonesia Pasca Putusan Mahkamah Konstitusi Nomor 48/PUU-IX/2011: dari Negative Legislator Menjadi Positive Legislator
}

\author{
Xavier Nugraha, Risdiana Izzaty, Alya Anira \\ Fakultas Hukum Universitas Airlangga \\ risdianaizzaty@gmail.com
}

Submit: 23-04-2019; Review: 06-04-2020; Terbit: 14-06-2020

\begin{abstract}
The Constitutional Court carrying out its duties regarding the constitutional review acts as a negative legislator which canceling laws that are contrary to the 1945 Constitution. This study examines the political shift of constitutional review law where the Constitutional Court only acts as a negative legislator, but nowadaysConstitutional Court acts as a positive legislator. The research method used is normative research. The results of this study conclude that the Constitutional Court Ruling reflects the role of a positive legislator is a progressive and responsive decision to avoid legal chaos due to legal vacuum in society. However, it does not mean that the decision of the Constitutional Court can always be a positive legislator. Only in circumstances based on 3 (three) indicators, namely: a) Justice and benefit of the community; b) An urgent situation; c) Filling out legal vacancies (rechtvacuum) to avoid chaos or legal chaos in the community, then the Constitutional Court Decision can be a positive legislator so that there is still a balance in the check and balances system.
\end{abstract}

Keywords: Constitutional Review, Positive Legislator, Negative Legislator.

\begin{abstract}
Abstrak
Mahkamah Konstitusi dalam menjalankan tugasnya terkait gugatan constitutional review berperan sebagai negative legislator yaitu membatalkan undang-undang yang bertentangan dengan UUD 1945. Namun, pasca Putusan Mahkamah Konstitusi Nomor 48/PUU-IX/2011, politik hukum gugatan constitutional review Mahkamah Konstitusi berubah menjadi positive legislator. Penelitian ini mengkaji tentang pergeseran politik hukum constitutional review yang dulunya, Mahkamah Konstitusi hanya sebagai negative legislator, namun kini menjadi positive legislator. Metode penelitian yang digunakan adalah penelitian normatif. Hasil dari penelitian ini menyimpulkan bahwa Putusan Mahkamah Konstitusi yang mencerminkan peran sebagai positive legislator merupakan putusan yang bersifat progresif dan responsif untuk menghindari kekacauan hukum akibat terjadi kekosongan hukum di dalam masyarakat. Akan tetapi, tidak berarti Putusan Mahkamah Konstitusi dapat selalu bersifat sebagai positive legislator. Hanya dalam keadaan berdasarkan 3 (tiga) indikator, yaitu: a) Keadilan dan kemanfaatan masyarakat; b) Situasi yang mendesak; c) Mengisi kekosongan Hukum (rechtvacuum) untuk menghindari chaos atau kekacauan Hukum dalam masyarakat, maka Putusan Mahkamah Konstitusi dapat bersifat positive legislator
\end{abstract}


agar tetap terjadi kesimbangan dalam sistem check and balances.

Kata Kunci: Constitutional Review, Positive Legislator, Negative Legislator.

\section{Pendahuluan}

Untuk memahami sistem constitutional review (pengujian konstitusional) yang dianut di Indonesia, maka harus memahami terlebih dahulu sejarah dari constitutional review tersebut. Dari akar sejarahnya, constitutional review sejatinya bersumber dari putusan fenomenal Supreme Court (Mahkamah Agung) Amerika dalam kasus "Marbury versus Madison" pada tahun 1803 (Arief Ainul Yaqin, 2018:10). Melalui putusan tersebutlah untuk pertama kalinya di dunia, suatu Undang-Undang dibatalkan karena bertentangan dengan Konstitusi. Setelah putusan tersebut, negara-negara di seluruh penjuru dunia, satu persatu mulai menerapkan constitutional review. Dalam catatan Jimly Ashiddiqie (2010:1-3) sudah ada lebih dari 100 negara yang menerapkan sistem constitutional review ini.

Menurut Mauro Cappellti (1989:133-135), terdapat 2 (dua) model constitutional review di dunia.
Model pertama adalah decentralized constitutional review, dimana model ini meletakkan kewenangan pengujian konstitusional secara tersebar kepada Mahkamah Agung dan lembaga peradilan di bawahnya. Contoh negara yang menggunakan model ini adalah negara pelopor constitutional review, yaitu Amerika. Model kedua adalah centralized constitutional review, dimana model ini meletakkan kewenangan pengujian konstitusional secara terpusat dengan cara membentuk suatu Mahkamah Konstitusi (selanjutnya disebut MK) sebagai organ khusus yang bertugas melakukan pengujian konstitusional. Model yang diinisiasi oleh Austria ini yang ternyata banyak digunakan oleh negara-negara di dunia, meskipun lahir belakangan, termasuk Indonesia.

Di Austria, yang notabenenya merupakan figur bagi Indonesia dalam melakukan judicial reviw, digunakan doktrinnegative legislator. Doktrin tersebut kali pertama diperkenalkan oleh Hans Kelsen 
dalam bukunya General Theory of Law and State (1945: 268-9). "The annulment of a law is a legislative function, an act-so to speak-of negative legislation. A court which is competent to abolish lawsindividually or generally-functions as a negative legislator."Sebagai penggagas MK modern pertama di dunia, Hans Kelsen mengemukakan doktrin tersebut untuk mendeferensiasi kewenangan antara MK dengan Parlemen di Austria(Pan Mohammad, 2016: 6). Menurut Hans Kelsen, pembentukan MK dimaksudkan untuk memiliki kewenangan sebagai negative legislator. Artinya, MK hanya dapat membatalkan undang-undang dan tidak dapat mengambil kewenangan Parlemen dalam membuat undangundang atau peraturan. Sebaliknya, Parlemen disebutnya sebagai positive legislator, karena memiliki kewenangan aktif untuk membuat Undang-Undang (Pan Mohammad Faiz, 2016:6-8).

Doktrin negative legislator ini kemudian juga digunakan sebagai salah satu teori pendukung dalam konteks separation of power di
Indonesia. Separation of powers yang dicetuskan oleh Montesquiemengacu pada teori trias politica dimana ia membagi kekuasaan negara secara horizontal menjadi 3 (tiga) cabang kekuasaan (Maasawet, 2016: 13) yakni kekuasaan legislative sebagai pembuat undang-undang, kekuasaan eksekutif untuk melaksanakan undang-undang, dan kekuasaan yudisiil untuk mengadili dan memutus perkara. Doktrin tersebut memuat mengenai larangan cabang kekuasaan dalam pemerintahan untuk ikut campur dalam urusan cabang kekuasaan lainnya sehingga menjamin independensi masingmasing cabang kekuasaan. Dalam konteks negative legislator adalah kewenangan antara MK dengan Dewan Perwakilan Rakyat (selanjutnya disebut DPR). Hal ini secara yuridis, dapat dilihat dalam Pasal 57 ayat (2a) Undang-Undang Nomor 4 Tahun 2014 tentang Pengesahan Penetapan Peraturan Pemerintah Pengganti UndangUndang Nomor 1 Tahun 2013 tentang Perubahan Undang-Undang Nomor 8 Tahun 2011 Tentang Perubahan Atas Undang-Undang Nomor 24 Tahun 
2003 tentang Mahkamah Konstitusi (selanjutnya disebut UU MK) dan diperjelas di dalam Pasal 36 Peraturan Mahkamah Konstitusi Nomor 06/PMK/2005 Tentang Pedoman Beracara Dalam Perkara. Dalam Pasal 57 ayat (2a), disebutkan bahwa: Putusan Mahkamah Konstitusi tidak meтuat:

a) amar selain sebagaimana dimaksud pada ayat (1) dan ayat (2);

b) perintah kepada pembuat undang-undang; dan

c) rumusan norma sebagai pengganti norma dari undangundang yang dinyatakan bertentangan dengan UndangUndang Dasar Negara Republik Indonesia Tahun 1945. (garis bawah dari penulis).

Berdasarkan pasal tersebut, dapat dilihat bahwa terdapat ketentuan tegas yang melimitasi MK, sehingga MK hanya sebagai pembatal norma dan tidak menempatkan dirinya sebagai perumus norma baru, karena hal tersebut merupakan kewenangan DPR bersama Presiden sebagai pembentuk Undang-Undang.

Dalam perkembangannya MK mengalami pergeseran fungsi dimana MK melalui putusannya sudah menjadi lembaga yang bersifat positive legislature. Hal ini dapat dilihat dalam praktiknya, dimana putusan MK yang bersifat positive legislature sangat banyak ditemukan dalam produk hukumnya. Muatan positive legislature dalam putusan MK dapat dilihat dengan adanya putusan MK yang menyatakan bahwa suatu ayat, pasal ataupun UndangUndang yang diuji diputus dengan putusan Conditionally Unconstitutional, Conditionally Constitutional, ataupun membuat rumusan baru terkait pasal atau ayat yang diujikan. Terkait kewenangan MK sebagai positive legislator ini kemudian juga dilegitimasi oleh MK dalam Putusan Mahkamah Konstitusi Nomor 48/PUU-IX/2011.

\section{Metode Penelitian}

Jenis penelitian yang digunakan adalah penelitian hukum normatif yaitu penelitian hukum kepustakaan, karena menjadikan bahan kepustakaan sebagai tumpuan utama (Rahmat GM Manik, 2017: 69).

Penelitian ini menggunakan 
pendekatan peraturan perundangundangan (statute approach), pendekatan konseptual (conceptual approach), dan pendekatan kasus (case approach).

Di lihat dari sifatnya, penelitian ini bersifat deskriptif, yaitu bertujuan menggambarkan secara tepat sifatsifat suatu individu, keadaan, gejala atau kelompok tertentu, atau untuk menentukan penyebaran suatu gejala, atau untuk menentukan ada tidaknya hubungan antara suatu gejala dengan gejala lain dalam masyarakat (Amirudin dan Asikin, 2010: 25).

Rumusan masalah yang diangkat dalam penelitian ini adalahmengkaji dan menganalisa adanya pergeseran politik hukum Constitutional Review di Indonesia pasca putusan MK Nomor48/PUU-IX/2011yang berkaitan dengan kewenangan MK menjadi positive legislator, dimana dulu MK hanyalah negative legislator.

\section{Hasil dan Pembahasan}

Politik Hukum Constitutional Review di Indonesia Pra Putusan MK No. 48/PUU-IX/2011
Konsep Trias Politica pertama kali diungkapkan oleh Montesquieu, dimana konsep Trias Politica adalah suatu prinsip normatif bahwa kekuasaan sebaiknya tidak diserahkan kepada orang yang sama untuk mencegah penyalahgunaan kekuasaan oleh pihak yang berkuasa (Miriam Budiardjo, 2005:152). Di Indonesia penerapan asas Trias Politica dapat dilihat dari pembagian kekuasaan dari segi fungsinya, yaitu:

a) Kekuasaan Legislatif, dimana memiliki fungsi untuk membuat undang-undang yang terdiri atas Majelis Permusyawaratan Rakyat (MPR), Dewan Perwakilan Rakyat (DPR), dan Dewan Perwakilan Daerah (DPD);

b) Kekuasaan Eksekutif, dimana memiliki fungsi untuk melaksanakan undang-undang yang telah dibuat oleh Legislatif. Kekuasaan ini dimiliki oleh Presiden;

c) Kekuasaan Yudikatif, dimana memiliki fungsi untuk mempertahankan undangundang yang telah dibuat oleh Legislatif dan berhak 
memberikan peradilan kepada rakyat. Kekuasaan ini dimiliki oleh Makhamah Agung (MA), Mahkamah Konstitusi (MK), dan Komisi Yudisial (KY).

Berdasarkan asas Trias Politica tersebut, terdapat pemisahan fungsi pembuatan undang-undang dengan mempertahankan undang-undang. Berdasarkan Pasal 20 ayat (1) Undang-Undang Dasar Negara Republik Indonesia Tahun 1945 DPR memegang kekuasaan untuk membentuk undang-undang. Berdasarkan pasal tersebut, tercermin peran Lembaga DPR sebagai positive legislator, dimana DPR memiliki kewenangan aktif untuk membuat undang-undang (Pan Mohamad Faiz, 2016:6-7). Kewenangan ini diwujudkan dengan 2 (dua) cara, yaitu (Montisa Mariana : 8):

a) Penyusunan Program Legislasi Nasional (Prolegnas), adalah instrumen perencanaan program pembentukan undang-undang yang disusun secara berencana, terpadu, dan sistematik;

b) Pengajuan Rancangan UndangUndang, dimana hal ini dapat dilaksanakan oleh Presiden, DPR, dan DPD.

Dengan adanya DPR sebagai lembaga yang memiliki peran positive legislator, MK hadir sebagai lembaga yang memiliki kewenangan untuk menguji materi yang termuat dalam undang-undang yang dibuat oleh Lembaga Legislatif. Kewenangan constitutional review ini diamanatkan dalam Pasal 24C ayat (1) UUD 1945 sertaPasal 10 UU MK. Sedangkan Pasal57 ayat (2a) UU MK merupakan cerminan peran sebagai negative legislator yakni menghapus atau membatalkan norma (Moh. Mahfud MD, 2008). MK tidak memiliki kewenangan untuk menambah norma di dalam suatu undang-undang yang mana hal tersebut merupakan kewenangan dari lembaga legislatif (Martitah, 2013:10). Denganadanya MK sebagai negative legislator dan legislatif sebagai positive legislator, hal tersebut merupakan salah satu bentuk perwujudan pemerintahan yang check and balances (Esfandiari dkk, 2014 : 3).

Berdasarkan undang-undang tersebut dijelaskan bahwa MK berperan sebagai negative legislator 
atau pembatal norma. Negative legislator sendiri dapat dimaknai sebagai tindakan MK yang dapat membatalkan norma dalam constitutional review undang-undang terhadap UUD 1945 atau membiarkan norma yang diberlakukan oleh lembaga legislatif tetap berlaku dengan menggunakan original intent UUD 1945 sebagai tolak ukurnya. Penerapan negative legislator yang dilakukan oleh MK merupakan salah satu bentuk dari judicial restraint. Teori ini pertama kali diungkapkan oleh James B. Thayer dalam tulisannya "The Origin and Scope of The American Doctrine of Constitutional Law" (1893). Teori ini berpandangan bahwa pengadilan perlu memiliki batasan atas kewenangan dan kemampuannya, sehingga mampu untuk menahan diri untuk tidak mengadili atau membuat kebijakan yang bukan berada di dalam ranah kewenangannya (Pan Mohamad Faiz, 2017:8-9).

Berdasarkan Naskah

Komprehensif Perubahan UndangUndang Dasar Negara Republik Indonesia Tahun 1945 Buku VI Kekuasaan Kehakiman, terdapat pemisahan kewenangan pengujian peraturan perundang-undangan antara MA dan MK, dimana dalam Naskah Komprehensif tersebut dibahas bahwa perlu adanya sebuah lembaga khusus, yaitu MK yang memiliki hak uji materiil atas undangundang terhadap Undang-Undang Dasar Negara Republik Indonesia Tahun 1945. Menurut Soewarno yang tertuang dalam Naskah Komprehensif tersebut, permasalahan yang ditangani MK bukan hanya permasalahan hukum murni saja. Berbeda dengan MA yang cenderung menyelesaikan masalah hukum murni, sehingga hak uji materiil undang-undang terhadap UndangUndang Negara Republik Indonesia Tahun 1945 diserahkan kepada MK.

Di samping adanya kekhususan pembahasan permasalahan hukum, pemberian kewenangan hak uji materiil undang-undang terhadap Undang-Undang Negara Republik Indonesia Tahun 1945 kepada MK dilatarbelakangi atas kedudukannya sebagai salah satu lembaga kekuasaan kehakiman. Di dalam Naskah Komprehensif Perubahan UndangUndang Dasar Negara Republik 
Indonesia Tahun 1945 Buku VI

Kekuasaan Kehakiman, kedudukan

MK sangatlah penting mengingat kewenangan uji materiil atas undangundang dan memberi putusan terhadap pertentangan antar undangundang. Keanggotaannya pun sangatlah khusus, dimana mereka diangkat langsung oleh MPR atas usul dari Presiden sebanyak 3 (tiga) orang, usul MA sebanyak 3 (tiga) orang, dan usul DPR sebanyak 3 (tiga) orang. Kedudukan MK pun dipandang sebagai guardian of constitution, dimana MK sebagai pelaku kekuasaan kehakiman yang dipandang sangat penting untuk mengawal keberlakuan UndangUndang Dasar Negara Republik Indonesia Tahun 1945.

Salah satu putusan MK yang mencerminkan fungsinya sebagai negative legislator adalah Putusan MK Nomor 6/PUU-V/2007. Dalam putusan tersebut, Pemohon mengajukan permohonan terkait constitutional review terhadap Pasal 154, Pasal 155, Pasal 160, Pasal 161, Pasal 207, Pasal 208, dan Pasal 107 KUHP atas Undang-Undang Dasar Negara Republik Indonesia Tahun
1945. Berdasarkan pertimbangan Majelis dalam perkara tersebut dan dengan mengkaji KUHP atas Undang-Undang Dasar Negara Republik Indonesia Tahun 1945, Majelis pun berpandangan bahwa ketentuan dalam Pasal 154 dan Pasal 155 KUHP telah bertentangan dengan Pasal 27 ayat (1), Pasal 28, Pasal 28C ayat (1), Pasal 28D ayat (1), Pasal 28E ayat (1), dan Pasal 28F UndangUndang Dasar Negara Republik Indonesia Tahun 1945 terkait dengan kebebasan berpendapat masyarakat Indonesia. Maka dari itu, Majelis pun memutus mengabulkan permohonan Pemohon sebagian dan dengan putusan tersebut dinyatakan bahwa Pasal 154 dan Pasal 155 KUHP tidak lagi memiliki kekuatan hukum yang megikat.

Menurut Hans Kelsen, keberadaan MK dalam suatu negara sangatlah penting. Di Indonesia, MK menjadi organ khusus yang menjamin keefektifan pelaksanaan aturan konstitusional tentang legislasi yang dibuat oleh badan legislatif sebagai pembuat produk hukum. Kedua organ tersebut memiliki kewenangannya masing-masing, dimana badan 
legislatif hanya dapat membuat produk hukum berupa legislasi. Nantinya, MK selaku organ yang memiliki fungsi constitutional review dapat melakukan pengontrolan keberlakuan legislasi tersebut. MK pun dapat menghapus legislasi tersebut apabila tidak sesuai dengan konstitusional. Melihat kembali kepada asas Trias Politica yang dianut oleh Indonesia, pemisahan kekuasaan antara pembuat dan penguji undang-undang ini dilakukan untuk menerapkan konsep bernegara yang diantara lembaganya akan saling lepas dalam kedudukan sederajat, sehingga dapat saling mengendalikan dan saling mengimbangi antara satu lembaga dengan lembaga yang lain (Efi Yulistyowati dkk, 2016:3). Selain itu, pemisahan kekuasaan ini pun dilakukan untuk menghindari kewenangan yang tumpang tindih pada satu lembaga dan menghindari sentralisasi kekuasaan.

Namun, seiring dengan perkembangan waktu, terdapat beberapa putusan MK yang terasa bahwa ia bersifat sebagai positive legislator atau pembuat norma. Beberapa putusan MK yang bersifat mengatur diantaranya Putusan No, 102/PUU-VII/2009, Putusan No. 4/PUU-VII/2009 dan Putusan No. 110-111-112-112/PUU-VII/2009.

\section{Politik Hukum Constitutional Review di Indonesia Pasca Putusan MK No. 48/PUU-IX/2011}

Seiring dengan berjalannya waktu, kewenangan yang dimiliki oleh MK tidaklah murni mengenai pengujian peraturan perundangundangan terhadap konstitusi seperti yang dikemukakan oleh Hans Kelsen. Pandangan "judge made law" di Amerika Serikat membuat Christopher Wolfe berpendapat bahwa telah terjadi pergeseran fungsi negative legislator menjadi positive legislator (Martitah, 2012: 317). Di Korea Selatan, Mahkamah Konstitusi diberi kewenangan untuk memutus konstitusionalitas undang-undang meskipun Pemohon tidak mengajukan permohonan tersebut, "The Constitutional Court shall decide only whether or not the requested statute or any provision of the statute is unconstitutional: Provided, that if it is deemed that the whole provisions of the statute are unable to enforce due to a decision of 
unconstitutionality of the requested provision, a decision of unconstitutionality may be made on the whole statute”. Sehingga terdapat keaktifan hakim dalam memutus sebuah perkara yang sangat menonjol pada praktiknya.

Selain itu, di beberapa negara telah diterapkan system baru yakni dalam hal pengujian peraturan perundang-undangan, $\mathrm{MK}$ tidak diberikan kewenangan untuk menetapkan peraturan perundangundangan tersebut inkonstitusional meskipun sudah jelas bertentangan dengan konstitusi. Melainkan kewenangan MK hanya sebatas untuk menginterpretasikan peraturan perundang-undangan yang diuji dengan konstitusi. Hal tersebut merupakan upaya untuk menghindari keadaan kekosongan hukum sehingga MK, yang serta-merta akan bertindak seperti positive legislator, harus membuat peraturan untuk mengisi kekosongan hukum atas peraturan perundang-undangan yang ditetapkan inkonstitusional sehingga tidak memiliki kekuatan hukum mengikat (Martitah, 2012: 317).
Di Indonesia, MK tetap menjunjung tinggi gelar negative legislator yang disandangnya. Namun, Moh. Mahfud MD menekankan bahwa terdapat beberapa putusan MK bersifat ultra petita (melebihi apa yang diajukan oleh Pemohon dalam petitum) sehingga mengarah pada intervensi ke ranah legislatif, hal tersebut berpotensi melanggar asas nemo judex in causa sua (larangan untuk memutus hal yang bersangkutan dengan MK sendiri), serta memuat putusan yang bersifat mengatur sehingga dianggap melampaui batas kewenangan yang dimiliki oleh MK sebagai negative legislator (Mahfud MD, 2009: 451). Martitah menyebutkan terdapat 3 (tiga) faktor yang menjadi dasar MK membuat putusan yang mengatur atau mempunyai karakteristik positive legislator, antara lain: (Martitah, 2013: 170)

1) Keadilan dan kemanfaatan masyarakat

MK sangat dimungkinkan tidak mematuhi ketentuan undangundang apabila hal tersebut digunakan untuk memenuhi 
keadilan substantif masyarakat. Hakim Konstitusi memiliki kewajiban untuk menggali rasa keadilan dalam masyarakat, oleh karena itu seringkali keadilan lebih diutamakan daripada kemanfaatan.

2) Situasi yang mendesak

Apabila MK menyadari adanya keterbatasan waktu, potensi terjadinya pelanggaran

konstitusional, atau menimbulkan kekacauan.

3) Mengisi kekosongan hukum (rechtvacuum) untuk menghindari chaos atau kekacauan hukum dalam masyarakat

Pasca dibatalkannya suatu undang-undang oleh MK dapat berdampak pada pelaksanaan undang-undang yang bersangkutan, sehingga Hakim Konstitusi dapat melakukan inovasi untuk mengisi kekosongan hukum.

Jadi tidak serta-merta MK telah bergeser dari negative legislator menjadi positive legislator, melainkan terdapat situasi-situasi yang harus dipertimbangkan oleh MK apabila ingin memutus perkara yang mengandung unsur positive legislator. Dalam perkembangannya, beberapa putusan MK yang mengandung unsur positive legislator dipandang sebagai langkah penegakan hukum yang progresif. Mengingat Hakim Konstitusi harus memiliki nurani yang menjunjung tinggi keadilan substantif untuk melindungi hak-hak konstitusional warga negara daripada mementingkan hal teknis prosedural (Martitah, 2012: 316). Keadilan substantif yang dimaksud adalah keadilan substansial, sebenarnya dan keadilan tersebut hadir dan dirasakan dalam masyarakat.

Pasal 45 ayat (1) UU MK menegaskan bahwa "Mahkamah Konstitusi memutus perkara berdasarkan Undang-Undang Dasar Negara Republik Indonesia Tahun1945 sesuai dengan alat bukti dan keyakinan hakim." Alat bukti dan keyakinan hakim itulah yang dijadikan dasar untuk menegakkan keadilan substantive melalui putusan yang dikeluarkan oleh MK. Maka seiring berjalannya waktu dikenal adanya putusan konstitusional 
bersyarat

(conditionally

constitutional),

inkonstitusional

bersyarat

(conditionally

unconstitutional), putusan sela dalam pengujian UU, putusan yang berlakusurut dan lain sebagainya (MKRI, 2010: 6).

Moh. Mahfud MD berpandangan apabila undang-undang tidak memberikan jalan hukum sehingga tidak terwujud kemanfaatan, diperlukan ketegasan sikap oleh Hakim Konstitusi dalam memutus perkara. Hakim Konstitusi harus mampu mengelaborasi pertimbangan serta fakta-fakta hukum dalam persidangan sebab UUDNRI 1945 memiliki 3 (tiga) tujuan utama yakni kepastian, keadilan, dan kemanfaatan (Esfandiari dkk, 2014: 6).

Konsep negative legislator tetap dipertahankan secara teoritis meskipun penerapannya sudah tidak sepenuhnya relevan lagi. Agar tercapainya hak-hak konstitusional warga negara, menghindari kekacauan serta menjamin kepastian hukum dalam keadaan yang mendesak, maka Hakim Konstitusi dituntut untuk melakukan interpretasi konstitusi. Hal tersebut diakui oleh mantan Hakim Konstitusi, Maruarar Siahaan (2003-2010), bahwa MK di Indonesia tidak lagi secara murni berperan sebagai negative legislator namun sebagai positive legislator pula (Pan Mohammad, 2016:7).

Salah satu putusan yang memiliki pengaruh cukup besar dalam pergeseran kewenangan MK dari negative legislator menjadi positive legislator adalah Putusan MK Nomor 48/PUU-IX/2011. Pemohon mengajukan constitutional review terhadap Pasal 45A dan Pasal 57 ayat (2a) huruf a dan huruf c UU MK yang dinilai membatasi kewenangan Hakim Konstitusi dalam membuat putusan sehingga Pemohon tidak mempunyai hak atas pengakuan, jaminan, perlindungan, dan kepastian hukum yang adil dengan Pasal 24 ayat (1) UUD NRI 1945.

Pasal 45A UU MK:

"Putusan Mahkamah Konstitusi tidak boleh memuat amar putusan yang tidak diminta oleh Pemohon atau melebihi Permohonan Pemohon, kecuali terhadap hal tertentu yang terkait dengan pokok permohonan;" Pasal 57 ayat (2a) huruf a UU MK: 
"Putusan Mahkamah Konstitusi tidak memuat: amar selain sebagaimana dimaksud pada ayat (1) dan ayat (2); ’”

Pasal 24 ayat (1) UUD NRI 1945

"Kekuasaan kehakiman merupakan kekuasaan yang merdeka untuk menyelenggarakan peradilan guna menegakkan hukum dan keadilan".

$$
\text { Pemohon berpendapat }
$$

bahwasanya kewenangan Mahkamah Konstitusi untuk menguji undangundang terhadap UUD 1945 sebagaimana diatur dalam Pasal 24C ayat (1) UUD 1945, tidak bisa dibatasi dengan hanya berpatokan dengan Permohonan Pemohon, tetapi juga diperbolehkan untuk memuat amar putusan yang tidak diminta oleh Pemohon atau melebihi permohonan Pemohon, sepanjang amar putusan tersebut bertujuan untuk menegakkan UUD 1945. Selain itu, kewenangan MK dalam pengujian undang-undang terhadap UUD 1945 tidak boleh dibatasi dengan hanya menyatakan materi muatan ayat, pasal, dan/atau bagian undang-undang bertentangan dengan UUD 1945, materi muatan ayat, pasal, dan/atau bagian undangundang tersebut tidak mempunyai kekuatan hukum mengikat, dan juga dibatasi dengan adanya larangan memuat rumusan norma sebagai pengganti norma dari undang-undang yang dinyatakan bertentangan dengan UUD 1945. Tetapi juga diperbolehkan untuk memuat putusan di luaritu, dalam hal ini berupa pemaknaan dan penafsiran, sepanjang amar putusan tersebut bertujuan untuk menegakkan UUD 1945.

Sebelum Putusan Nomor 48/PUU-IX/2011, MK juga telah membuat putusan yang memuat amar putusan yang bersifat ultra petita. Selain itu. MK juga telah mengeluarkan putusan yang memuat penafsiran dan pemaknaan berupa putusan konstitusional bersyarat (conditionally constitutional) dimana apabila tafsir MK sesuai maka undang - undang tersebut tetap bersifat konstitusional; dan inkonstitusional bersyarat (conditionally unconstitutional) dimana apabila tafsir MK dirasa tidak sesuai maka undang-undang tersebut dinyatakan bertentangan dengan UUD 1945 dan tidak memiliki kekuatan hukum mengikat (Rahman dan Wicaksono, 2016: 352). 
MK mendalilkan bahwa karakter hukum acara di MK terutama dalam perkara pengujian undang-undang terhadap UUD 1945 adalah untuk mempertahankan hak dan kepentingan konstitusional yang dilindungi oleh konstitusi, sebagai akibat berlakunya suatu undangundang yang berlaku umum (ergaomnes). Oleh karena itu, apabila kepentingan umum menghendaki, Hakim Konstitusi tidak terpaku hanya pada permohonan atau petitum yang diajukan sehingga berdasarkan prinsip ex aquo et bono, hakim dapat menjatuhkan putusan yang adil dan patut menurut hukum.

MK juga mendalilkan salah satu tujuan kewenangan constitutional review yang diberikan kepada MK adalah untuk membenahi hukum. Maka Hakim Konstitusi wajib menggali, mengikuti, dan memahami nilai-nilai hukum dan rasa keadilan yang hidup dalam masyarakat guna pembentukan hukum baru melalui putusan-putusan MK untuk menjaga agar tidak terjadi kekosongan hukum. Sedangkan pasal-pasal tersebut menghalangi MKuntuk: a) Menguji konstitusionalitas norma.Apabila Pemohon mengajukan constitutional review yang ternyata berkaitan dengan undang-undang lainnya, namun tidak dicantumkan dalam petitum sehingga menyebabkan ketidakpastian hukum. MakaMKdapatmembuatputusan yang berkaitandenganundangundang yang diuji konstitusionalitasnya apabila terdapat akibat hukum yang berkaitan satu sama lain dengan undang-undang yang tidak diajukan constitutional review.

b) Mengisi kekosongan hukum sebagai akibat putusan MK yang menyatakan suatu norma bertentangan dengan UUD 1945 dan tidak memiliki kekuatan hukum mengikat.

Proses pembentukan undangundang membutuhkan waktuyang cukup lama, sehingga tidak dapat segera mengisi kekosongan hukum tersebut. Berikut merupakan target dan capaian dalam Prolegnas 20152019 oleh legislatif: 
Tabel 1

Target dan capaian Prolegnas 2015-2019

\begin{tabular}{ccc}
\hline Tahun & Target Prolegnas & Capaian Prolegnas \\
\hline 2015 & 40 & 3 \\
2016 & 50 & 10 \\
2017 & 52 & 6 \\
2018 & 50 & 5 \\
2019 & 55 & 10 \\
\hline
\end{tabular}

Sumber: Forum Masyarakat Peduli Parlemen Indonesia, 2019

Dengan proses prosedural yang panjang, setiap tahunnya hanya ada rata-rata 7 RUU yang berhasil dibahas, maka hal tersebut berpotensi terjadinya kekosongan hukum pasca putusan MK yang menyatakan bahwa undang-undang atau ketentuan di dalamnya tidak memiliki kekuatan mengikat. Maria Farida berpendapat bahwa mekanisme legislative review membutuhkan waktu yang lama sehingga MK-lah yang seharusnya mengambil langkah untuk melakukan perubahan hukum melalui putusan mahkamah. Hal tersebut akan lebih mencerminkan tindakan preventif yang diambil oleh MKuntuk melindungi hak konstitusional warga negara daripada harus menunggu keputusan legislatif yang berpotensi tidak tercapainya keadilan substantif dalam masyarakat.

c) Melaksanakan kewajiban Hakim Konstitusi untuk menggali, mengikuti, dan memahami nilainilai hukum dan rasa keadilan yang hidup dalam masyarakat.

Digunakan untuk mencapai keadilan substantif di masyarakat.

Berdasarkan dalil-dalil yang telah disampaikan oleh MK, dalil tersebut dapat dipandang sebagai 
lampu hijau bagi Hakim Konstitusi untuk menjadi positive legislator.Namun, bahwasanya tetap harus mempertimbangkan dalam situasi apa saja MK dapat berperan sebagai positive legislator. Sebab apabila MK dalam setiap memutus perkara menjadikan dirinya sebagai positive legislator, hal tersebut akan mengganggu kewenangan dari legislatif sebagai positive legislator sesungguhnya.

Lalu, apakah berarti pergeseran kewenangan MK dari negative legislator menjadi positive legislator tersebut mencederai prinsip trias politica? Jimly Assidiqie berpendapat bahwa Indonesia telah mengalami 4 (empat) kali amandemen UUD 1945 sehingga seiring berjalannya waktu terdapat pergeseran doktrin yang terjadi di dalamnya. Secara eksplisit, UUD1945 telah membagi cabang kekuasaan sesuai dengan doktrin separation of powers menurut teori trias politica yaitu legislatif, eksekutif, dan yudisiil seperti yang telah dicetuskan oleh Montesquie. Namun, secara implisit UUD 1945 setelah amandemen ke-4 (empat), doktrin tersebut telah bergeser menjadi system pemisahan kekuasaan yang bersifat check and balances yaitu pemisahan kekuasaan dengan pengawasan dan penyeimbangan di tiap cabang kekuasaan dalam pemerintahan (Budiyanto, 2016: 10). MK sebagai salah satu lembaga yudisiil yang diatur oleh UUD 1945 sepenuhnya memegang peran sebagai negative legislator namun tidak sepenuhnya sebagai positive legislator. MK sewaktu-waktu bertindak sebagai positive legislator pada situasi-situasi tertentu saja sehingga terdapat peran yang saling melengkapi antara yudisiil dan legislatif dimana hal tersebut sesuai dengan prinsip check and balances.

\section{Simpulan}

Politik hukum Constitutional Review di Indonesia mulai mengalami pergeseran pasca Putusan Mahkamah Konstitusi Nomor 48/PUU-IX/2011. Bukan lagi hanya berperan sebagai negative legislator, namun, Mahkamah Konstitusi juga berperan sebagai positive legislator. Perubahan politik hukum ini didasarkan agar Mahkamah Konstitusi benar-benar dapat menjalankan tugasnya sebagai 
guardian of human rights secara substansial, dimana Mahkamah Konstitusi tidak terhambat oleh procedural justice, sehingga dapat meraih substantive justice. Meskipun Mahkamah Konstitusi bergeser menjadi positive legislator bukan hanya negative legislator, namun bukan berarti Mahkamah Konstitusi dapat selalu berperan sebagai positive legislator. Hanya dalam keadaan tertentulah Mahkamah Konstitusi dapat menjadi positive legislator. Keadaan tersebut berdasarkan 3 (tiga) indikator yaitu : a) Keadilan dan kemanfaatan masyarakat; b) Situasi yang mendesak; c) Mengisi kekosongan hukum (rechtvacuum) untuk menghindari chaos atau kekacauan hukum dalam masyarakat. Selain dari keadaan yang memenuhi 3 (tiga) indicator tersebut, maka Mahkamah Konstitusi tidak dapat menjalankan fungsinya sebagai positive legislator, melainkan hanya sebagai negative legislator. Hal ini agar tetap terjadi kesimbangan dalam sistem check and balances antara fungsi legislatif dan yudisiil.

\section{Daftar Pustaka}

\section{Buku}

Achmad, Mukti Fajar dan Yulianto. 2010, Dualisme Penelitian Hukum Normatif dan Empiris. Yogyakarta: Pustaka Pelajar.

Amirudin dan Zainal Asikin. 2010, Pengantar Metode Penelitian Hukum. Jakarta: Rajawali Pers.

Asshiddiqie, Jimly. 2010, ModelModel Pengujian Konstitusional di Berbagai Negara. Jakarta: Sinar Grafika.

Budiardjo, Miriam. 2005, DasarDasar Ilmu Politik. Jakarta: Gramedia Pustaka Utama.

Cappelleti, Mauro. 1989, The Judicial Process in Comperative Perspective. Oxford: Calrendon Pess.

Faiz, Pan Mohammad. 2016, Relevansi Doktrin Negative Legislator, Majalah Konstitusi No. 108. Jakarta: Mahkamah Konstitusi.

Kelsen, Hans. 1949, General Theory of Law and State. Cambridge: Harvard Unity Pess.

MD, Mahfud.2009, Konstitusi dan Hukum Dalam Kontroversi Isu. Jakarta: Rajawali Pers.

Martitah. 2013, Mahkamah Konstitusi dari Negative Legislature ke Positive 
Legislature?. Jakarta:

Penerbit Konstitusi Press (Konpress).

Republik Indonesia, Mahkamah Konstitusi. 2010, Mengawal Demokrasi Menegakkan Keadilan Substantif. Jakarta : Sekjen dan Kepaniteraan Mahkamah Konstitusi.

Yaqin, Arief Ainul. 2016, Constitutional Question: Kewenangan yang Terlupakan dan Gagasan untuk Melembagakannya di Makhamah Konstitusi. Jakarta: Sinar Grafika.

\section{Jurnal}

Ahmadi. 2014, Konstitusional Review: Suatu Perbandingan Praktek Ketatanegaraan, AlIzzah 9 (1)

Esfandiari, Fitria dkk. 2012, Positive Legislature Mahkamah Konstitusi di Indonesia, Jurnal Hukum1 (2)

Hoecke, M.V.2011, Legal doctrine: Which method(s) for what kind of discipline?, HART Publishing, Oxford.

Manik, Rahmat GM. 2016, Pemutusan Hubungan Kerja Atas Kesalahan Berat Setelah Pasal 158 Undang-Undang Nomor 13 Tahun 2003 Tentang Ketenagakerjaan Dicabut Oleh Putusan Mahkamah Konstitusi Nomor 012/PUU-I/2003.
Melayunesia Law 1 (1)

Martitah.2012, Progresivitas Hakim Konstitusi Dalam Membuat Putusan (Analisis Terhadap Keberadaan Putusan Mahkamah Konstitusi yang Bersifat Positive Legislature), Masalah-Masalah Hukum 41

Qamar, Nurul. 2012, Kewenangan Judicial Review Mahkamah Konstitusi. Jurnal Konstitusi 1 (1)

Rahman, Faiz dan Dian Agung Wicaksono. 2016, Eksistensi dan Karakteristik Putusan Bersyarat Mahkamah Konstitusi, Jurnal Konstitusi, $13(2)$

Yulistyowati, Efi dkk. 2016, Penerapan Konsep Trias Politica Dalam Sistem Pemerintahan Republik Indonesia: Studi Komparatif atas Undang-Undang Dasar Tahun 1945 Sebelum dan Sesudah Amandemen. Jurnal Dinamika Sosial Budaya 18 (2)

\section{Peraturan Perundang-Undangan}

Undang-Undang Dasar Negara Republik Indonesia Tahun 1945.

Undang-Undang Nomor 4 Tahun 2014 tentang Pengesahan Penetapan Peraturan Pemerintah Pengganti Undang-Undang Nomor 1 Tahun 2013 tentang Perubahan Undang-Undang 
Nomor 8 Tahun 2011 Tentang Perubahan Atas UndangUndang Nomor 24 Tahun 2003 tentang Mahkamah Konstitusi (Lembaran Negara Republik Indonesia Tahun 2003 Nomor 98, TambahanLembaran Negara Republik Indonesia Nomor 4316).

\section{Skripsi, Thesis, Disertasi}

Budiyanto, Agung. 2016, Mahkamah Konstitusi Sebagai Positive Legislature (Studi Putusan Nomor 28/PUU-XI/2013 dan Putusan Nomor 85/PUU-XI/2013). Skripsi, Universitas

Muhammadiyah Surakarta.

Maasawet, Sukma. 2016, Mahkamah Konstitusi Sebagai Policy Maker Menggantikan Pembentuk Undang-Undang. Thesis, Universitas Kristen Satya Wacana.

\section{Website}

Faiz, Pan Mohamad. 2017, Judicial Restraint vs Judicial Activism, Kolom Opini Majalah Konstitusi, No. 130. [Diakses 9 April 2019] https://panmohamadfaiz.co $\underline{\mathrm{m} / 2017 / 12 / 31 / \text { judicial- }}$ restraint-vs-judicialactivism/

Naskah Komprehensif Perubahan

Undang-Undang Dasar Negara Republik Indonesia Tahun 1945 Buku VI Kekuasaan Kehakiman.[Diakses 9
April 2019] https://mkri.id/index.php?p $\underline{\text { age }=\text { download.NaskahKo }}$ $\underline{\text { mprehensif\&id }=8}$ 